\title{
Abundance, biomass and community structure of pond phytoplankton related to the catchment characteristics
}

\author{
Elzbieta Zębek ${ }^{*}$ and Urszula Szymańska \\ University of Warmia and Mazury, Faculty of Law and Administration, Department of International Public Law, Warszawska 98, \\ 10-702 Olsztyn, Poland
}

\begin{abstract}
Studies were conducted in 2010 on phytoplankton assemblages in ponds in North-East Poland with catchment areas in village environments, mid-forest, mid-meadow and mid-field settings. Differences in phytoplankton abundance, biomass and structure and the environmental requirements of dominant species were assessed in the studied ponds. These features were related to variable physicochemical water parameters and nutrient presence; with the highest phytoplankton abundance and biomass dominated by chlorophytes and diatoms in the village ponds and the greatest diversity of species' assemblages recorded in the mid-forest and mid-field ponds. In addition, CCA analysis of general trends in phytoplankton growth determined that $\mathrm{NH}_{4}$ and $\mathrm{TN}$ enhanced growth in the mid-meadow and mid-field ponds, and $\mathrm{P}_{-} \mathrm{PO}_{4}$ and $\mathrm{pH}$ influenced growth in the mid-forest pond. The relationships established in this study between phytoplankton and environmental conditions can directly influence future directions in small water-body conservation.
\end{abstract}

Keywords: phytoplankton / ponds / catchment character / nutrients / CCA

Résumé - Abondance, biomasse et structure communautaire du phytoplancton de mares de différents bassins versants. Les études ont été menées en 2010 sur des assemblages de phytoplancton dans des mares dans le nord-est de la Pologne avec des bassins versants en milieu villageois, forestier, prairial et cultivé. Des différences dans l'abondance, la biomasse et la structure du phytoplancton et les exigences environnementales des espèces dominantes ont été évaluées dans les mares étudiées. Ces caractéristiques étaient liées aux paramètres physicochimiques variables de l'eau et à la présence de nutriments; avec la plus grande abondance et biomasse de phytoplancton dominée par les chlorophytes et les diatomées dans les mares du village et la plus grande diversité d'assemblages d'espèces enregistrés dans les mares du milieu forestier et cultivé. En outre, l'analyse CCA des tendances générales de la croissance du phytoplancton a déterminé que la croissance accrue par NH4 et TN dans les mares prairiale et en champ cultivé, et que le P$\mathrm{PO} 4$ et le pH ont influencé la croissance dans la mare forestière. Les relations établies dans cette étude entre le phytoplancton et les conditions environnementales peuvent influencer directement les orientations futures dans la conservation des petites mares.

Mots-clés : phytoplancton / étang / bassin versant / nutriment / CCA

\section{Introduction}

While biodiversity is mainly directed to nature protection areas under European Union guidelines, especially in Nature 2000 sites and reserves (Directive 92/43/EEC), ponds are very important because they contribute to increase of national aquatic biodiversity and catchment functions. Ponds also create links between existing aquatic habitats and provide ecosystem services such as nutrient interception, hydrological regulation

\footnotetext{
*Corresponding author: elzbieta.zebek@uwm.edu.pl
}

and natural scenery enrichment (Carvalho et al., 1995; Biggs et al., 2005; Lombardo, 2005; Gligora et al., 2007; Céréghino et al., 2008a,b, 2014). Pond surface water quality is largely dependent on different land use in agriculture and village life and consequent catchment environments. These small water bodies differ greatly in origin and in morphological conditions such as surface area, depth and volume, and natural and anthrophogenically altered ponds experience different precipitation, insolation, water temperature and catchment nutrient inflow. This great variability therefore contributes to forming different habitats and increasing organism species diversity (Wiliams et al., 2008). 
Phytoplankton with different environmental requirements profit from changes in water physicochemical parameters and their assemblages therefore differ. While phytoplankton are critical to the pond food chain, providing food for the multiplicity of animals, fish and invertebrates, they occasionally form blooms (Celewicz-Gołdyn et al., 2008). Phillips et al. (2008) and Teissier et al. (2012) also consider that nutrients are the main determinants of phytoplankton biomass levels in lakes and ponds.

The hypothesis asserts that pond catchment character affects the physicochemical water parameters and subsequent development and differentiation of phytoplankton assemblages. The purpose of this study was to determine the differences in phytoplankton abundance, biomass, structure, species diversity and environmental requirements of dominant species related to the physicochemical water parameters in village, mid-meadow, mid-field and mid-forest pond catchment areas.

\section{Materials and methods}

\subsection{Study area}

The phytoplankton study concentrated on ponds; small water bodies located in the Jonkowo village adjacent to Warmińskie Buczyny Nature 2000 sites and Kamienna Góra reserve in the Warmia Mazury Region of North-East Poland. The study area has 8 ponds with different catchment character: 2 in each of the village (VIP), mid-meadow (MEP), mid-forest (FRP) and mid-field (FLP) environments (Fig. 1).

- VIPs: The 3000 and $400 \mathrm{~m}^{2}$ Weqgajty village ponds have $1.5 \mathrm{~m}$ maximum depth and the urbanized catchment areas $(100 \%)$ close to a major road promote polluted inflow to the ponds. The pond banks are overgrown by macrophytes; dominated by Typha latifolia L. One pond is connected to fish ponds, and while one bank of the second pond has underground outflow with a surplus of spring waters flowing towards the village centre, the remaining banks are clay and sandy and the bottom of the pond is muddy.

- MEPs: The 80 and $50 \mathrm{~m}^{2}$ mid-meadow ponds are natural small water bodies with maximum 0.5 and $0.8 \mathrm{~m}$ depths, have muddy bottoms and are surrounded by meadows $(68 \%)$ and pastures $(32 \%)$. They contain the following macrophytes: Myriophyllum spicatum L., Acorus calamus L., Iris pseudacorus L., Spirodela polyrhiza (L.) Schleid. and Lemna minor L.

- FRPs: The mid-forest ponds have natural character with $2000 \mathrm{~m}^{2}$ and $1.5 \mathrm{ha}$ areas at 1.5 and $1 \mathrm{~m}$ maximum depth, respectively. The first pond is based on peat and surrounded by coniferous forest, while the second lies in mixed forest near the Buczyny Warmińskie Nature 2000 sites. These ponds have $100 \%$ forest catchment areas. They contain the Ricciocarpos natans L. macrophyte characteristic of static acidic waters and peat pits, and also Spirodela polyrhiza (L.) Schleid., Lemna minor L., Calla palustris L., Iris pseudacorus L. and Menyanthes trifolia L.

- FLPs: The two mid-field ponds are small water bodies with 7 and $200 \mathrm{~m}^{2}$ area and maximum $0.5 \mathrm{~m}$ depth. They have approximately $70 \%$ agricultural and $30 \%$ pasture catchment areas and form water-holes for cattle and horses. The first pond is overgrown by Typha latifolia L., Eriophorum vaginatum L., Lemna minor L., Lemna trisulca L. and Polygonum amphibium L., and the second by Acorus calamus L., Phragmites australis (Cav.) Trin. Ex Steud, Spirodela polyrhiza (L.) Schleid. and Lemna minor L.

\subsection{Materials and methods}

Phytoplankton samples were collected at the same time in three seasons (April, July and October) in 2010 at 8 ponds of different catchments: village (VIP), mid-meadow (MEP), midforest (FRP) and mid-fields (FLP) ponds. The samples were taken from euphotic zone of the surface open water with a $10 \mathrm{~L}$ calibrated bucket ( $20 \mathrm{~L}$ at each site), sieved through a plankton net no. 25 and preserved with a Lugol's solution and then with a $4 \%$ formaldehyde solution. In total, 24 phytoplankton samples were tested. The following physicochemical properties were measured directly at the phytoplankton sampling sites: water temperature with $0.1^{\circ} \mathrm{C}$ precision and oxygen content exact to $0.01 \mathrm{mg} \mathrm{O}_{2} \mathrm{~L}^{-1}$ (HI 9143 oxygen meter), and $\mathrm{pH}$ and electrolytic conductivity at $1-1500 \mu \mathrm{S} \mathrm{cm}^{-1}$ (CONMET 1).

The following groups of phytoplankton, were analyzed in this study; cyanobacteria, diatoms, chlorophytes, dinoflagellates, chrysophytes, and cryptomonads. Qualitative and quantitative determinations of phytoplankton were performed with an Alphaphot YS2 optical microscope at magnifications of $100 \times, 200 \times, 400 \times$ and $1000 \times$. Numbers in $1 \mathrm{~mL}$ samples of phytoplankton were determined in 5000 fields of vision with $200 \times$ magnification in each planktonic chamber to account for differences in organism densities and their abundance and biomass expressed in identical basic $1 \mathrm{~mL}$ volumes. Diatoms were prepared following the standard method in Battarbee (1979). Algal biomass for 10 individuals was calculated by comparing algae with their geometric shape (Rott, 1981). The scope of water analysis in the laboratory included: orthophosphates $\mathrm{P}-\mathrm{PO}_{4}, \mathrm{TN}$ and $\mathrm{N}-\mathrm{NH}_{4}$ concentrations using Spectroquant Merck tests with NOVA 400 spectrophotometer.

\subsection{Statistical analysis}

In the analysis, means were applied as the average values of phytoplankton abundance or biomass from the three months (April, July and October) separately in each from 8 studied ponds in 2010. The mean values of water physicochemical properties were calculated in the same way. The standard deviations were also calculated. In addition, the $\mathrm{chi}^{2}$-square test was used for comparing the differences in phytoplankton community structure. The species diversity for phytoplankton abundance was analyzed to calculate the Shannon-Wiener index (Shannon and Weaver, 1949; Maurer and McGill, 2011). The modified $t$-test (Hutcheson, 1970) was used to statistically comparison of the species diversity.

Total algal abundance and biomass, and abundance of taxonomic groups and dominant species were correlated with physical and chemical water parameters using non-parametric methods because these data are not normally distributed (test Shapiro-Wilk, STATISTICA version 10). To reduce the 


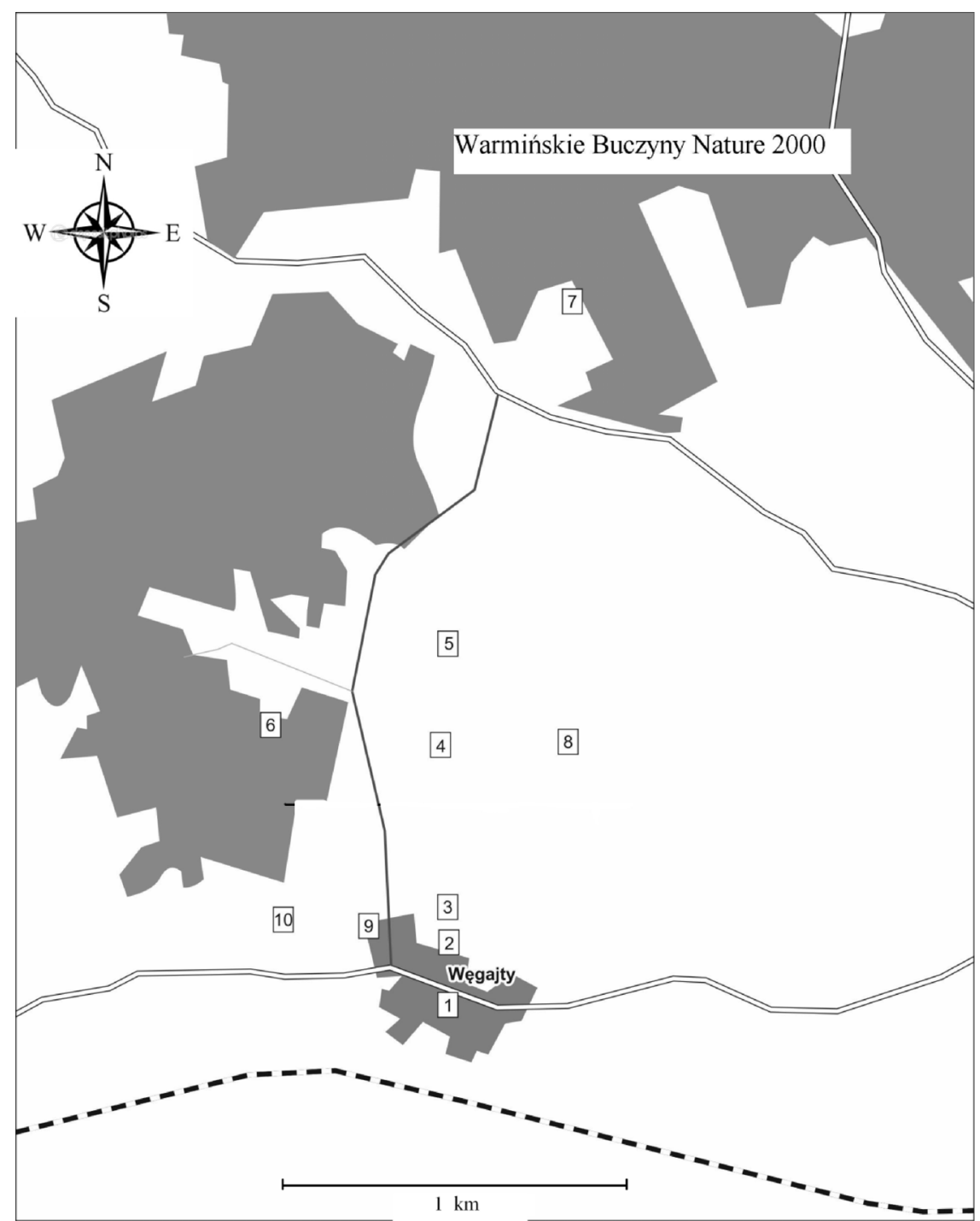

Fig. 1. Map of pond localization: 1,9-village (VLP), 4, 5- mid-meadow (MEP), 6, 7 - mid-forest (FRP) and 8, 10 - mid-fields (FLP) ponds, NE Poland. Black bar is distance reference of $1 \mathrm{~km}$.

number of variables a forward selection procedure using the Monte Carlo test with 999 permutations. Relationships were confirmed by calculating Spearman's rank correlation coefficient (significance at $p<0.05$ ) with STATISTICA version 10 . A canonical correspondence analysis CCA was performed to relate water chemistry variables to phytoplankton abundance and biomass, phytoplankton groups and dominant species. Finally, these relationships were presented on a biplots graph using Canoco for Windows 4.5 software.

\section{Results}

\subsection{Physicochemical water parameters}

The study recorded the following differences in the physicochemical properties (Tab. 1):

- the lowest water temperature and oxygenation, and the highest conductivity $\left(466 \mu \mathrm{S} \mathrm{cm}^{-1}\right)$ and orthophosphates $\left(2.22 \mathrm{mg} \mathrm{PO}_{4} \mathrm{~L}^{-1}\right)$ in mid-meadow ponds (MEP);
- the lowest $\mathrm{N}-\mathrm{NH}_{4}$ and TN, and the highest water temperature of $18.8^{\circ} \mathrm{C}$ and $\mathrm{pH}$ of 8.29 in village ponds (VLP);

- the highest oxygen content of $7.35 \mathrm{mg} \mathrm{O}_{2} \mathrm{~L}^{-1}$ and the lowest conductivity of in mid-forest ponds (FRP);

- the lowest $\mathrm{pH}$ and $\mathrm{P}-\mathrm{PO}_{4}$, and the highest $\mathrm{N}-\mathrm{NH}_{4}$ $\left(0.22 \mathrm{mg} \mathrm{L}^{-1}\right)$ and $\mathrm{TN}\left(1.5 \mathrm{mg} \mathrm{L}^{-1}\right)$ in mid-field ponds (FLP).

\subsection{Differentiation of phytoplankton abundance and biomass}

The lowest mean abundance and biomass was found in MEP (2672 ind. $\mathrm{mL}^{-1}$ and $0.02 \mathrm{mg} \mathrm{mL}^{-1}$ ) and the highest abundance in VLP (17 166 ind. $\mathrm{mL}^{-1}$ ) and biomass in FRP (0.16 $\mathrm{mg} \mathrm{mL}^{-1}$ ) (Fig. 2).

The chi $^{2}$-square tests exhibited significance level at 0.001 indicating significantly differences between community structure of phytoplankton abundance $(174.1, p<0.0001)$ and biomass $(170.71, p<0.0001)$. Phytoplankton abundance 
Table 1. Physicochemical water parameters (mean \pm standard deviations) in village (VLP), mid-meadow (MEP), mid-forest (FRP) and midfields (FLP) ponds in 2010.

\begin{tabular}{llccc}
\hline Water parameters & VLP & MEP & FRP & FLP \\
\hline Water temperature $\left({ }^{\circ} \mathrm{C}\right)$ & $18.8 \pm 7.0$ & $15.3 \pm 2.1$ & $17.3 \pm 2.8$ & $17.1 \pm 5.6$ \\
Oxygen content $\left(\mathrm{mg} \mathrm{O}_{2} \mathrm{~L}^{-1}\right)$ & $3.27 \pm 2.17$ & $1.40 \pm 0.09$ & $7.35 \pm 4.71$ & $5.03 \pm 3.90$ \\
$\mathrm{pH}$ & $8.29 \pm 0.30$ & $7.94 \pm 0.03$ & $8.18 \pm 0.52$ & $7.29 \pm 1.19$ \\
Conductivity $\left(\mathrm{nS} \mathrm{cm}^{-1}\right)$ & $432 \pm 153$ & $466 \pm 51$ & $147 \pm 106$ & $194 \pm 117$ \\
Ammonium $\left(\mathrm{mg} \mathrm{NH}_{4} \mathrm{~mL}^{-1}\right)$ & $0.17 \pm 0.03$ & $0.21 \pm 0.03$ & $0.20 \pm 0.12$ & $0.22 \pm 0.19$ \\
Total nitrogen $\left(\mathrm{mg} \mathrm{N} \mathrm{mL}^{-1}\right)$ & $1.0 \pm 1.2$ & $1.1 \pm 1.4$ & $1.0 \pm 1.6$ & $1.5 \pm 1.4$ \\
Orthophosphates $\left(\mathrm{mg} \mathrm{PO}_{4} \mathrm{~L}^{-1}\right)$ & $1.40 \pm 1.02$ & $2.29 \pm 0.20$ & $1.46 \pm 1.33$ & $0.18 \pm 0.01$ \\
\hline
\end{tabular}

was dominated by chlorophytes in VLP and FLP $(78.9 \%$ and $55.0 \%$, respectively) and diatoms in the remaining ponds, MEP $-55.4 \%$ and FRP $-45.6 \%$, while dinoflagellates in MEP and euglenins in FRP reached a significant proportion of total phytoplankton abundance. Cyanobacteria had the low $4.3 \%$ abundance in FLP. In the case of phytoplankton biomass, chlorophyte share amounted to $85.3 \%$ in FRP and diatom share amounted to $78.9 \%$ in MEP. Other algal groups contributed in less than $10.0 \%$ of the phytoplankton biomass (Fig. 3).

\subsection{Phytoplankton diversity and dominant species}

The highest Shannon-Wiener species diversity index was recorded for phytoplankton in FLP at 4.86 bit ind. $^{-1}$ and the lowest in VLP at 2.49 bit ind. $^{-1}$ at 60 and 96 taxa, respectively (Tab. 2). The $t$-tests were significant at 0.001 indicating differences between VLP and MEP, VLP and FRP, VLP and FLP, MEP and FRP but not between MEP and FRP $(p=0.6250$, Tab. 3).

The Euclidean diagram demonstrated that the greatest similarity in species composition is shown by the smallest distance between algae in FLP and FRP, and the least similarity was between algae in FLP and VLP (Fig. 4). CCA analysis also highlights the greatest similarity between phytoplankton in MEP and FLP and the most difference in FRP.

These phytoplankton assemblages were dominated by chlorophytes and diatoms (Fig. 3). Cyanobacteria were represented by Aphanizomenon gracile and chlorophytes by the genera Chlamydomonas sp. in all ponds, and Spirogyra sp. (FRP), Closterium cynthia (FRP, FLP), Closterium echrenbergii (MEP, FLP), Pediastrum duplex and Monoraphidium concortum (VLP), Ulothrix tenuissima (MEP) and Pediastrum boryanum species (FLP). Diatoms were represented by Pinnularia sp. and Fragilaria capucina (MEP) and Diatoma vulgaris var. linearis (FRP) and Diatoma vulgaris (VLP, FLP), euglenins by Euglena viridis and Euglena acus, cryptomonads by Cryptomonas sp. and dinoflagellates by Peridinium sp. genera.

\subsection{Relationships between phytoplankton and physicochemical water parameters}

The Monte Carlo test revealed that the correlation between phytoplankton abundance and biomass, phytoplankton groups and dominant species and physicochemical properties from the canonical correspondence analysis was significant both for Axis 1 and Axis 2 (eigenvalue 0.032 and
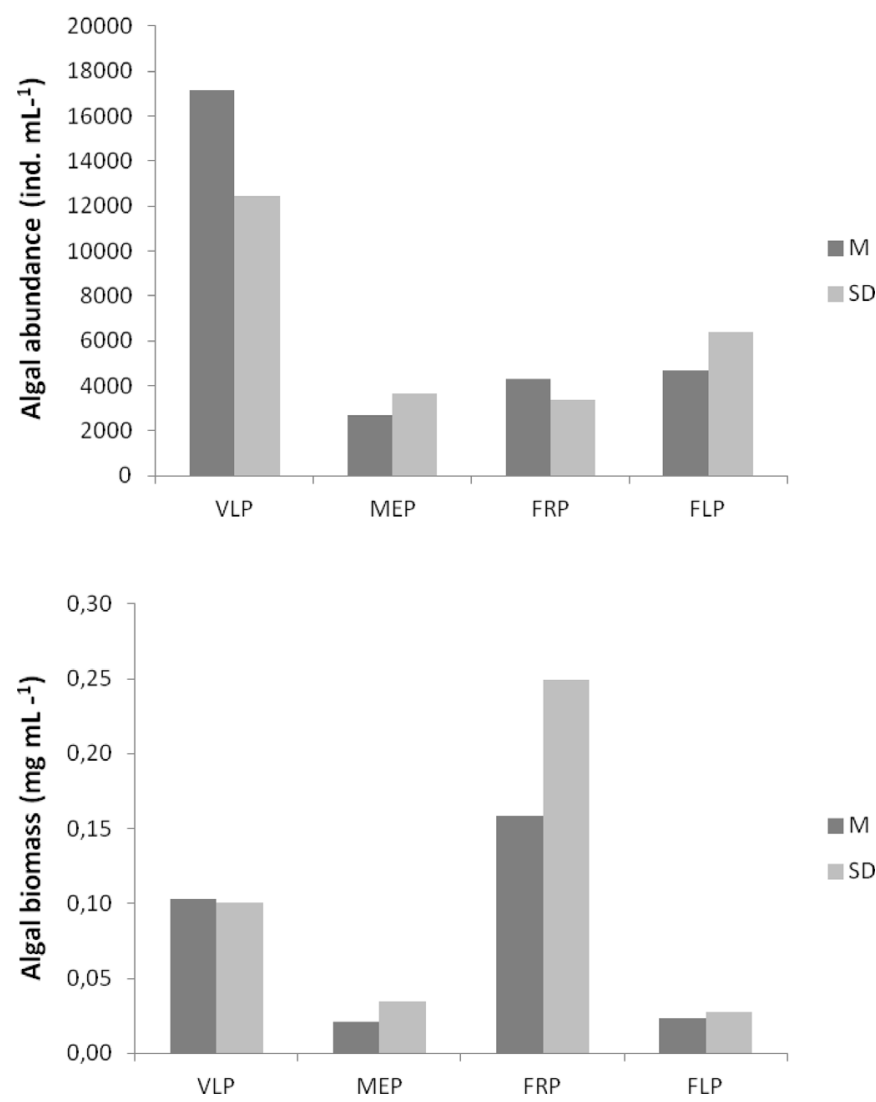

Fig. 2. Mean abundance and biomass (M), and standard deviations (SD) of phytoplankton in village (VLP), mid-meadow (MEP), midforest (FRP) and mid-fields (FLP) ponds in 2010.

$0.022,0.295$ and 0.185 , and 0.801 and 0.628 , respectively). CCA analysis shows that $\mathrm{N}-\mathrm{NH}_{4}$ and $\mathrm{TN}$ most commonly promoted algal growth in MEP and FLP, $\mathrm{P}_{-} \mathrm{PO}_{4}$ in FRP (Fig. 5). Chlorophytes were mainly correlated with temperature and $\mathrm{P}_{-} \mathrm{PO}_{4}$ in FLP, cyanobacteria and euglenins with $\mathrm{O}_{2}$ in VLP, while dinophytes with $\mathrm{pH}$ in FRP, and dinophytes and diatoms with TN in VLP and MEP (Fig. 6). The data in Figure 7 show correlation between phytoplankton species and physicochemical variables confirming these tendencies. Similarly, chlorophyte and cyanobacterial species correlated with temperature, $\mathrm{P}_{-} \mathrm{PO}_{4}$ and $\mathrm{pH}$ in MEP and FLP and diatoms with $\mathrm{O}_{2}$ and $\mathrm{N}-\mathrm{NH}_{4}$ in FLP, FRP, VIP, and with TN in MEP. The following correlations were determined between 

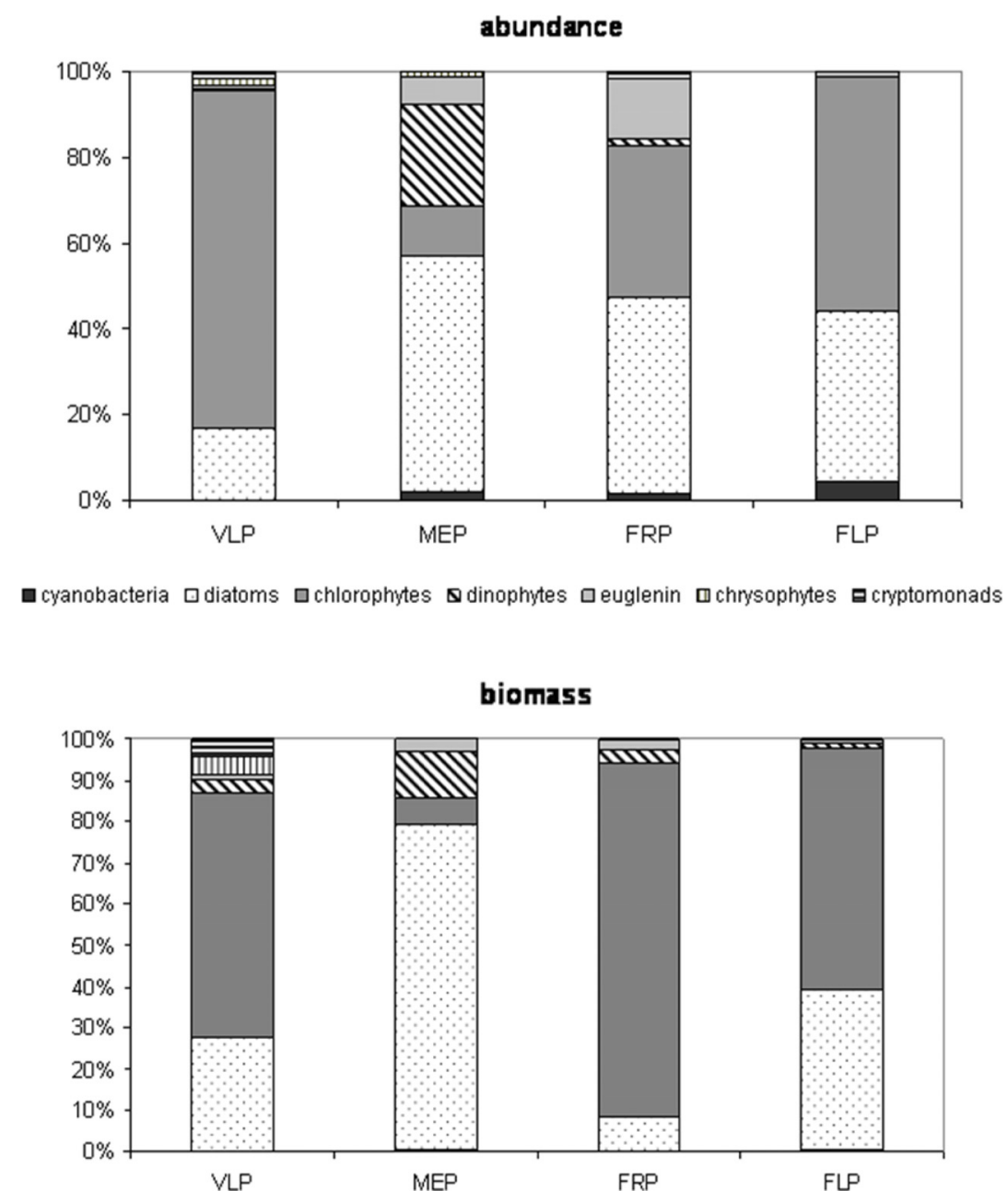

Fig. 3. Structure of phytoplankton in village (VLP), mid-meadow (MEP), mid-forest (FRP) and mid-fields (FLP) ponds in 2010.

phytoplankton species and physicochemical water parameters at $p<0.05$ :

- Positive correlations: Diatom species Amphora veneta correlated with oxygen content $(r=0.46)$, Diatoma vulgaris, Cocconeis placentula, Fragilaria ulna, Navicula gregaria, Pinularia sp. and Nitzschia palea with $\mathrm{N}_{-} \mathrm{NH}_{4}$ $(r=0.47, r=0.48, r=0.56, r=0.54, r=0.62$ and $r=0.51$, respectively) and the following correlated with $\mathrm{pH}$; Amphora veneta at $r=0.49$ and Fragilaria delicatissima at $r=0.55$ and euglenin species Euglena acus at $r=0.46$.

- Negative correlations

- diatom species: Diatoma vulgaris and C. placentula correlated with conductivity $(r=-0.73$ and $r=-0.54$, respectively);

- diatoms: $F$. delicatissima and F. ulna $(r=-0.56$ and $r=-0.47$, respectively), and the genera Trachelomonas sp. $\quad(r=-0.49)$ and Cryptomonas sp. $(r=-0.56)$ correlated with $\mathrm{P}_{-} \mathrm{PO}_{4}$;

- chlorophytes: the genus Spirogyra sp. and species Pediastrum boryanum correlated with $\mathrm{N}^{-\mathrm{NH}_{4}}$ ( $r=-0.53$ and $r=-0.47$, respectively);

- genus Trachelomonas sp. correlated with water temperature $(r=-0.50)$.

\section{Discussion}

The limited water depth and volume and type of catchment area ensured great variability in the environmental conditions of the studied ponds. Moreover, the biotic and abiotic parameters can be very seasonally unstable (Joniak et al., 2006). These especially related to the density and quality of fish and invertebrate communities and physical factors including temperature and available nutrients. In this study, high conductivity and orthophosphates recorded in midmeadow ponds (MEP) and the highest $\mathrm{N}-\mathrm{NH}_{4}$ and $\mathrm{TN}$ in midfield ponds (FLP) agree with similar investigation into field ponds by Kocarkova et al. (2004) and Celewicz-Gołdyn et al. (2008). This is related to land use practices in the ponds' vicinity affecting the catchments by nutrient loading and fertilizer and pesticide contamination (Declerck et al., 2006). Moreover, intensified agriculture has far more influence at pond catchment scale than in larger river and lake catchment areas (Céréghino et al., 2008a). Similar to Owsianny and Gąbka's (2006) and Celewicz-Gołdyn et al. (2008) results in dystrophic small water bodies, the highest oxygen content and the lowest conductivity were recorded in mid-forest ponds (FRP). 
Euclidean distance

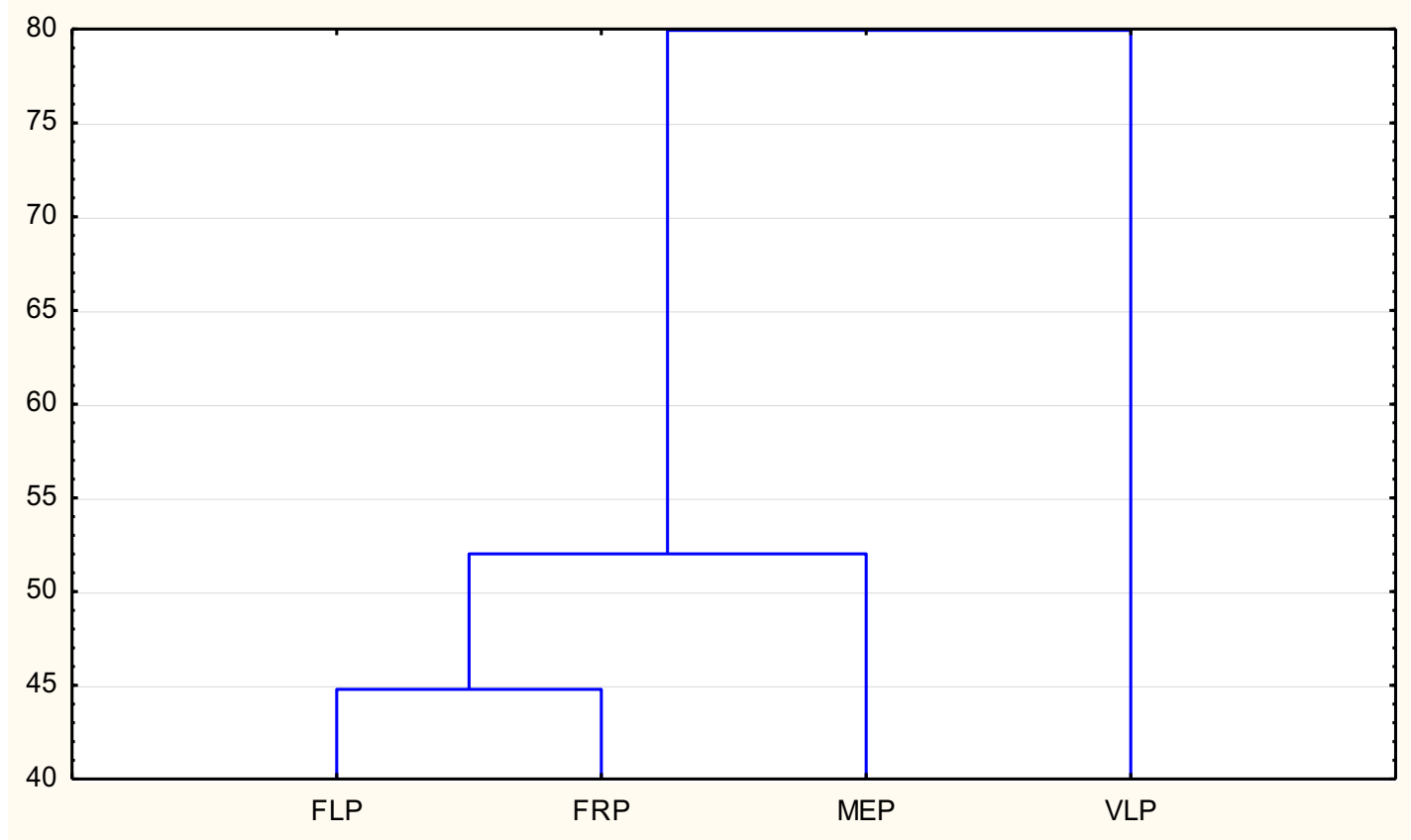

Fig. 4. Euclidean diagram of species phytoplankton similarity in village (VLP), mid-meadow (MEP), mid-forest (FRP) and mid-fields (FLP) ponds in 2010.

Table 2. Species diversity Shannon-Wiener's indices based for the logarithms of phytoplankton abundance in village (VLP), mid-meadow (MEP), mid-forest (FRP) and mid-fields (FLP) ponds in 2010.

\begin{tabular}{|c|c|c|c|c|}
\hline Ponds & VLP & MEP & FRP & FLP \\
\hline Shannon-Wiener species diversity index (ind. bit ${ }^{-1}$ ) & 2.49 & 4.00 & 4.52 & 4.86 \\
\hline Number taxa & 95 & 58 & 62 & 60 \\
\hline
\end{tabular}

Table 3. Comparison species diversity expressed as Shannon-Wiener's between of phytoplankton in village (VLP), mid-meadow (MEP), midforest (FRP) and mid-fields (FLP) ponds in 2010. The values of the $t$-test, corresponding to $F$ statistic value and associated $p$-values $(p)$ are displayed for each comparison.

\begin{tabular}{llll}
\hline Ponds & $t$ & $F$ & $p$ \\
\hline VLP-MEP & -0.31 & 4.20 & $p<0.0001$ \\
VLP-FRP & -0.44 & 3.69 & $p<0.0001$ \\
VLP-FLP & -0.08 & 206.45 & $p<0.0001$ \\
MEP-FRP & -0.07 & -1.13 & $p=0.6250$ \\
MEP-FLP & -0.02 & 47.96 & $p<0.0001$ \\
\hline
\end{tabular}

While some authors reported clear associations between algal assemblages and a variety of environmental factors such as surface area, catchment character and nutrient loading (Boix et al., 2008; Céréghino et al., 2008b; Gascon et al., 2008; Oertli et al., 2008), this study determined differences in pond algal abundance and biomass based on catchment area type. Although Kocarkova et al. (2004) found a low abundance of algae communities in mid-forest ponds and higher algal densities in mid-field ponds due to high nutrient concentrations, despite high $\mathrm{P}_{-} \mathrm{PO}_{4}$ and $\mathrm{N}-\mathrm{NH}_{4}$. In this study, the lowest mean abundance and biomass was found in MEP, and the highest abundance in VLP and biomass in FRP at the highest water temperature and $\mathrm{pH}$, and oxygen content, respectively. 


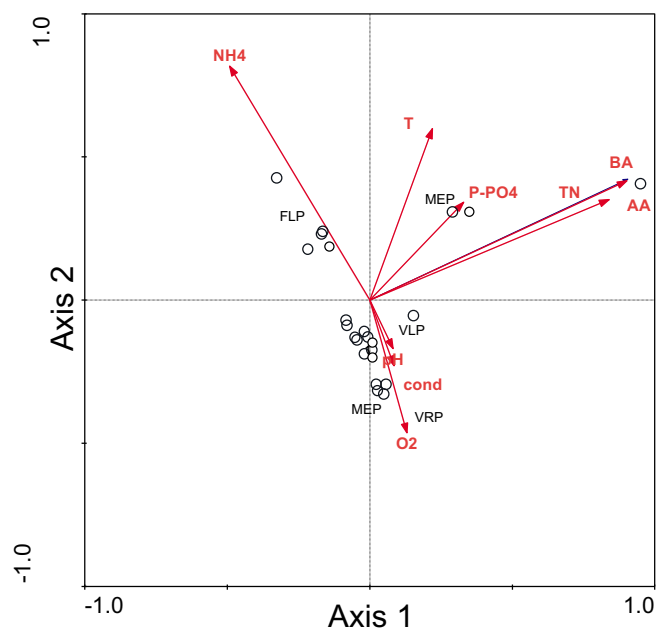

Fig. 5. CCA analysis physicochemical water parameters forming phytoplankton growth (AA - algal abundance, BA - algal biomass) in village (VLP), mid-meadow (MEP), mid-forest (FRP) and midfields (FLP) ponds in 2010.

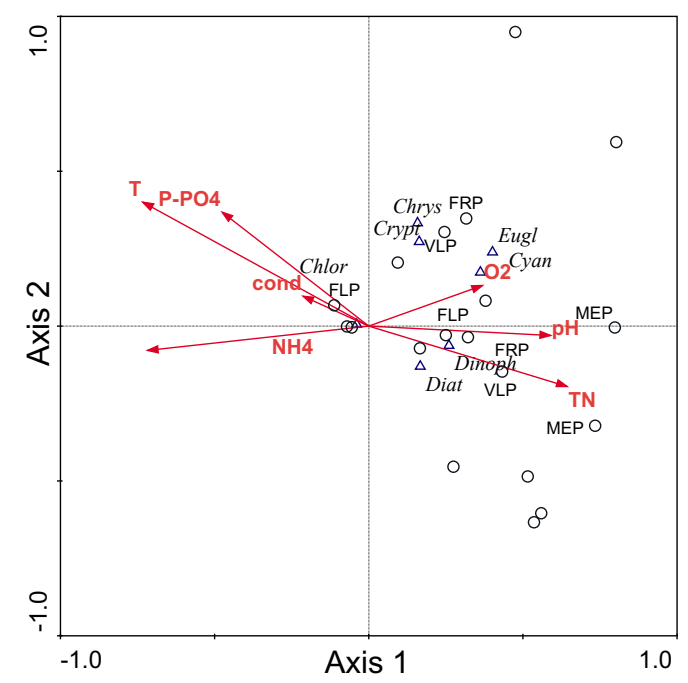

Fig. 6. CCA analysis between phytoplankton taxonomic groups (Cyan - cyanobacteria, Diat - diatoms, Chlor - chlorophytes, Dinoph - dinophytes, Eugl - euglenins, Chrys - chrysophytes, Crypt - cryptomonads) and physicochemical water parameters in village (VLP), mid-meadow (MEP), mid-forest (FRP) and mid-fields (FLP) ponds in 2010.

CCA analysis illustrated that high $\mathrm{N}-\mathrm{NH}_{4}$ in MEP and FLP and low $\mathrm{P}_{-} \mathrm{PO}_{4}$ in FRP determined phytoplankton growth. These water parameters influenced particular phytoplankton group growth. Similar to Celewicz-Gołdyn et al. (2008) findings, high percentages of chlorophytes and diatoms composed the taxonomical structure in the studied ponds. This was especially noticeable in the positive relationships of high $\mathrm{N}-\mathrm{NH}_{4}$ with the highest proportion of chlorophytes in total FLP phytoplankton abundance and high oxygenation with diatoms in the FRP. In addition, nutrient-rich MEP and FLP waters enhanced dinoflagellates growth and high water

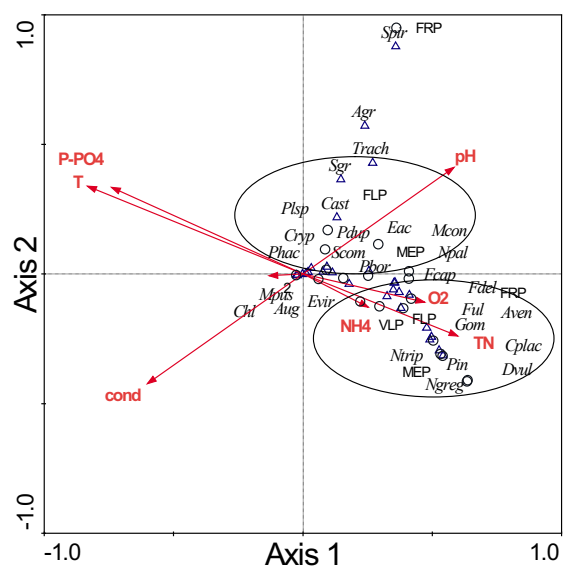

Fig. 7. CCA analysis between dominant species of taxonomic phytoplankton groups (Agr-Aphanizomenon gracile, AugAulacoseira granulata, Aven - Amphora veneta, Chl - Chlamydomonas spp., Cplac - Cocconeis placentula, Cast - Coleastrum astroideum, Cryp - Cryptomonas sp., Dvul - Diatoma vulgaris, Eac - Euglena acus, Evir - Euglena viridis, Fcap - Fragilaria capucina, Fdel - Fragilaria delicatissima, Ful - Fragilaria ulna, Gom - Gomphonema spp., Mpus - Micratinium pusillum, Mcon Monoraphidium concortum, Ngreg - Navicula gregaria, Ntrip Navicula tripunctata, Npal - Nitzschia palea, Pin - Pinnularia sp., Pbor - Pediastrum boryanum, Pdup - Pediastrum duplex, Phac Phacus sp., Plsp - Planctoccoccus sphaerocystiformis, Scom Scenedesmus communis, Sgr - Staurastrum gracile, Spir - Spirogyra sp., Trach - Trachelomonas sp.) and physicochemical water parameters (cond - conductivity) in village (VLP), mid-meadow (MEP), mid-forest (FRP) and mid-fields (FLP) ponds in 2010.

temperature stimulated cryptomonad development in the VIP. Moreover, low percentage share of cyanobacteria in the study ponds suggests that nutrient availability (especially P) was probably insufficient to trigger cyanobacteria blooms (Downing et al., 2001).

Della Bella et al. (2008) reported that high phytoplankton species richness is characteristic of small water bodies, and this was especially evident in nutrient-rich FLP waters. Moreover, the lowest diversity (Shannon-Wiener index) in VLP is most likely related to high chlorophyte domination; especially by genera Chlamydomonas spp. In addition to differences in species diversity, there was also differentiation in algal species composition. The greatest similarity in species composition is shown between algae composition in FLP and FRP, and the least similarity was between algae in FLP and VLP. CCA analysis also confirmed similarity between phytoplankton in MEP and FLP, while the most distinctive were in FRP. Phytoplankton in the studied ponds was characteristic for small water bodies, with chlorophyte and diatom domination accompanied by cyanobacteria and euglenin presence (Kuczyńska-Kippen and Nagengast, 2006; Napiórkowska-Krzebietke et al., 2011; Asha Nair et al., 2015).

This study results agree with the findings in agricultural ponds reported by various authors (Sahin, 2000; KuczyńskaKippen and Nagengast, 2006; Asaduzzaman et al., 2010; Napiórkowska-Krzebietke et al., 2011), where the diatoms Diatoma, Fragilaria, Pinularia, Melosira, Navicula, Nitzschia, Pediastrum and Scenedesmus dominated together with 
Euglena and Phacus. Diatom genera Pinnularia sp., Diatoma vulgaris and Fragilaria capucina dominated MEP and FLP ponds with chlorophytes Closterium echrenbergii, Ulothrix tenuissima and Pediastrum boryanum. Euglenins Euglena viridis and Euglena acus, genus Phacus sp. and Trachelomonas sp. were present in these and other pond types with Peridinium sp. dinoflagellates and Aphanizomenon gracile cyanobacteria. Dinoflagellates were often noted in mesotrophic waters and cyanobacteria in eutrophic waters, with euglenophytes common and abundant in the natural shallow water bodies and cryptomonads ubiquitous (Hašler et al., 2008). In addition, the presence of Euglena, Phacus, and dinoflagellates in some ponds suggests a high availability of dissolved organic matter (DOM), as these algae can complement photosynthesis with organic matter uptake from the water column (Taylor and Pollingher, 1987). Moreover, the greatest abundance of the genus Chlamydomonas in nutrientrich water was registered in VLP, accompanied by Monoraphidium concortum and Diatoma vulgaris and Cryptomonas sp. The eutrophic environments especially contained large unicellular elongate Closterium sp., the filamentous Mougeotia sp., Spirogyra sp. and Chlamydomonas sp. flagellates (NaselliFlores and Barone, 2000; Hašler et al., 2008; Asha Nair et al., 2015). In addition, Closterium cynthia, Pediastrum duplex and Spirogyra sp. chlorophytes and Diatoma vulgaris var. linearis dominated in FRP; corresponding with Owsianny and Gąbka (2006) mid-forest pond results.

Differentiation between diatoms, chlorophytes and others algal groups is closely allied to the availability of their preferred physicochemical parameters in the particular pondtypes. This further explains the environmental differences determined by CCA analysis for the correlations between diatom dominant species and oxygen (Amphora veneta), N$\mathrm{NH}_{4}$ (Diatoma vulgaris, Cocconeis placentula, Fragilaria ulna, Navicula gregaria, Pinularia sp. Nitzschia palea); and $\mathrm{pH}$ (Apmhora veneta, Fragilaria delicatissima). Asaduzzaman et al. (2010) also reported that Diatoma, Fragilaria, Pinularia, Nitzschia often correlated with nitrogenous compounds; especially in agricultural ponds. In addition, this study highlighted low water temperature favoured Trachelomonas sp. growth, chlorophyte Spirogyra sp. and Pediastrum boryanum abundance increased at low $\mathrm{N}^{-\mathrm{NH}_{4}}$ and Euglena acus at high $\mathrm{pH}$.

Phytoplankton-nutrient relationships are widely used by lake managers to asses eutrophication and set nutrient targets (Teissier et al., 2012), and phytoplankton can remove phosphorous and nitrogen pollutants from ponds (Céréghino et al., 2014). This is related with the following nutrient uptake resulting in negative correlations between algal species and N$\mathrm{NH}_{4}$ (Spirogyra sp., Pediastrum boryanum), conductivity (D. vulgaris, C. placentula) and $\mathrm{P}_{-} \mathrm{PO}_{4}(F$. delicatissima, F. ulna, Trachelomonas sp. and Cryptomonas sp.).

\section{Conclusion}

Their catchment area type and small surface area and volume make these ponds susceptible to accelerated eutrophication from their particular environments, and phytoplankton type is an evident coefficient of this phenomenon. Anthrophogenic activity also exerts impact through agricultural field fertilization and village proximity.
Our results confirm these phenomena, where the highest phytoplankton abundance was recorded in the nutrient-rich village ponds. Moreover, phytoplankton assemblages were characterized by high biodiversity, differentiated structure and differences in environmental requirements for dominant species. The studied assemblages have great biodiversity and their consequent ecological role warrants special protection. Moreover, our results highlight important future directions for conservation of these ponds and the protection of their biodiversity; especially for those water bodies located in close proximitylized to the natural protected areas of Nature 2000 sites.

Acknowledgement. This study was supported by the Grant No. 00092/10/62011/OP-PO/D of the WFOS iGW in Olsztyn, Poland.

\section{References}

Asha Nair MS, Reshma J, Anu Mathew K, Aswathy Ashok JA. 2015. Effect of water quality on phytoplankton abundance in selected ponds of Nedumangad Block Panchayat, Kerala. Emerg Life Sci Res 1: 35-40.

Asaduzzaman M, Rahman MM, Azim ME, Ashraful Islam M, Wahab MA. 2010. Effects of $\mathrm{C} / \mathrm{N}$ and substrate addition on antural food communities in freshwater prawn monoculture ponds. Aquaculture 306: $127-136$.

Battarbee RW. 1979. Diatoms in lake sediments. In: International Geological Correlation Programme Project 158, Paleohydrological Changes in the Temperate Zone in the Last 15, 000 Years. Subproject B, Lake and Mire Environments. Lund, Sweden: Dept. of Quaternary Geology.

Biggs J, Williams P, Whitfield P, Nicolet P, Weatherby A. 2005. 15 years of pond assessment in Britain: results and lessons learned from the work of Pond Consevation. Aquat Conserv Mar Freshw Ecosyst 15: 693-714.

Boix D, Gascon S, Sala J, et al. 2008. Patterns of composition and species richness of crustaceans and aquatic insects along envirobmental gradients in mediaterraen water bodies. Hydrobiologia 597: 53-69.

Carvalho L, Beklioglu M, Moss B. 1995. Changes in a deep lake following sewage diversion - a challenge to the orthodoxy of external phosphorus control as a restoration strategy? Freshwater Biol 34: 399-410.

Celewicz-Gołdyn S, Kuczyńska-Kippen N, Nagengast B. 2008. Phytoplankton community structure in two types (forest vs. field) of small water bodies. Botanika-Steciana 12: 23-28.

Céréghino R, Biggs J, Oertli B, Declerck S. 2008a. The ecology of European ponds: defining the characteristics of a neglected freshwater habitat. Hydrobiologia 597: 1-6.

Céréghino R, Ruggiero A, Marty P, Angelibert S. 2008b. Biodiversity and distribution patterns of freshwater invertebrates in farm ponds of southwestern French agricultural landscape. Hydrobiologia 597: $43-51$.

Céréghino R, Boix D, Cauchie H-M, Martens K, Oertli B. 2014. The ecological role of ponds in a changing world. Hydrobiologia 723: $1-6$.

Council Directive. 1992. Council Directive 92/43/EEC of 21 May 1992 on the conservation of natural habitats and of wild fauna and flora, OJ L 206, 22 July 1992.

Declerck S, De Bie T, Ercken D, et al. 2006. Ecological characteristics of small ponds: associations with land-use practices at different spatial scales. Biol Conserv 131: 523-532. 
Della Bella V, Bazzanti M, Dowgiallo MG, Iberite M. 2008. Macrophyte diversity and physic-chemical characteristics of Tyrrhenian coast ponds in central Italy: implications for conservation. Hydrobiologia 579: 85-95.

Downing JA, Watson SB, McCauley E. 2001. Predicting cyanobacteria dominance in lakes. CanJ Fish Aquat Sci 58: 1905-1908.

Gascon S, Boix D, Sala J, Quintana D. 2008. Relation between macroinvertebrate life strategies and habitat traits in Mediterranean salt marsh ponds (Emporda wetlands, NE Iberan Peninsula). Hydrobiologia 597: 71-83.

Gligora M, Plenković-Moraj A, Kralj K, Grigorszky I, Peroš-Pucar D. 2007. The relationship between phytoplankton species dominance and environmental variables in a shallow lake (Lake Vrana, Croatia). Hydrobiologia 584: 337-346.

Hašler P, Štěpánková J, Špačková J, et al. 2008. Epipelic cyanobacteria and algae: a case study from Czech ponds. Fottea 8: $133-146$.

Hutcheson K. 1970. A test for comparing diversities based on the Shannon formula. J Theor Biol 29: 151-154.

Joniak T, Kuczyńska-Kippen N, Nagengast B. 2006. Chemistry of waters of small water bodies in the agricultural landscape of the western Wielkopolska region. Teka Komisji Ochrony S rodowiska Przyrodniczego 8: 60-65.

Kocarkova A, Duchoslav M, Poulickova A. 2004. The variation of phytoplankton in different types of floodplain ponds: a case study from the River Morava floodplain (the Czech Republik). Chech Phycology, Olomouc 4: 87-102.

Kuczyńska-Kippen N, Nagengast B. 2006. The impact of a sudden water level decrease on the biocenotic structure of a small pastoral water body. Teka Komisji Ochrony Środowiska Przyrodniczego 3: 104-114.

Lombardo P. 2005. Applicability of littoral food-web biomanipulation for lake management purposes: snails: macrophytes, and water transparency in northeast Ohio shallow lakes. Lake Reserv Manag 21: $186-202$.
Maurer BA, McGill BJ. 2011. Measurement of species diversity. In: Magurran AE, McGill BJ, eds. Biological diversity: frontiers in measurement and assessment. Oxford: Oxford University Press, pp. 55-65.

Napiórkowska-Krzebietke A, Hutorowicz A, Tucholski S. 2011. Dynamics and structure of phytoplankton in fishponds fed with treated wastewater. Pol J Environ Stud 20: 157-166.

Naselli-Flores L, Barone R. 2000. Phytoplankton dynamics and structure: a comparative analysis in natural and man-made water bodies of different trophic state. Hydrobiologia 438: 65-74.

Owsianny PM, Gąbka M. 2006. Spatial heterogeneity of biotic and abiotic habitat conditions of the lake-bog ecosystem Kuźniczek (NW Poland). Limnol Rev 6: 223-231.

Oertli B, Indermuehle N, Angelibert S, Hinden H, Stoll A. 2008. Macroinvertebrate assemblages in 25 high alpine ponds of the Swiss National park (Cirque of Macun) and relation to environmental variables. Hydrobiologia 597: 29-41.

Phillips G, Pietilainen OP, Carvalho L, Solimini A, Solheim AL, Cardoso AC. 2008. Chlorophyll-nutrient relationships of different lake types using a large European dataset. Aquat Ecol 42: 213-226.

Rott E. 1981. Some results from phytoplankton counting intercalibrations. Schweiz Z Hydrol 43: 34-62.

Sahin B. 2000. Algal flora of lakes Aygyr and Balykly (Trabzon, Turkey). Turk J Bot 24: 35-45.

Shannon CE, Weaver W. 1949. The mathematical theory of communication. Urbana.

Taylor FJR, Pollingher U. 1987. Ecology of dinoflagellates. In: Taylor FJR, ed. The biology of flagellates. Oxford: Blackwell Scientific Publisher, pp. 398-529.

Teissier S, Peretyatko A, De Backer S, Triest L. 2012. Strength of phytoplankton-nutrient relationship: evidence from 13 biomanipulated ponds. Hydrobiologia 689: 147-159.

Wiliams P, Whitfield M, Biggs J. 2008. How can we make new ponds biodiverse? - a case monitored over 8 years. Hydrobiologia 597: 137-148.

Cite this article as: Zębek E, Szymańska U. 2017. Abundance, biomass and community structure of pond phytoplankton related to the catchment characteristics. Knowl. Manag. Aquat. Ecosyst., 418, 45. 